\title{
A MUTILAÇÃO DO SAGRADO: A POÉTICA PROFANA EM ALEIJÃo, DE EDUARDO STERZI
}

\author{
Nicia Petreceli ZUCOLO ${ }^{43}$
}

STERZI, E. Aleijão. Rio de Janeiro: 7Letras, 2009.

\section{Trouxeste a chave?}

Eis a eterna e temível pergunta de Drummond... Eis a questão das questões: a chave...

A chave, nesse caso, é exigida tanto para quem se arvora a ler, quanto a escrever poesia; ambos sacerdotes, iniciados, místicos, prestidigitadores da palavra (e da técnica) são revestidos de uma sacralidade indesejada, que afasta - do poema - a sua matéria viva... que afasta - do poema - a matéria que o mantém vivo: o leitor.

Essa sacralidade não diz respeito à força da palavra substantiva, a nomear existências pelo canto ritual. Essa sacralidade é a ideia recorrente de que é necessário ser algum tipo de iniciado para compreender a poesia, entendida como composição que envolve temas elevados, manifestos por palavras obscuras, exigindo vasta cultura geral de um público, normalmente contemplativo, que não se reconhece no texto.

Para ilustrar a hipérbole apresentada (e reconhecida), pensemos na profanação de Augusto dos Anjos, de um Ferreira Gullar, trazendo o nojo, a corporeidade da gosma, da palavra suja, para a poesia, asséptica e sagrada. É fato que exagero, que recorto apenas este aspecto para chegar ao ponto que pretendo, mas também é fato que a poesia sempre ocupou no imaginário popular o espaço do erudito, do inalcançável, do nefelibata... e poetas como Gregório de Matos, Glauco Mattoso, Augusto dos Anjos, e um Ferreira Gullar, escapam ao lírico como o senso comum prevê, muito próximo, nesse aspecto, de Aristóteles, com a sua poética do nobre.

\footnotetext{
${ }^{43}$ Departamento de Língua e Literatura Portuguesa, Instituto de Ciências Humanas e Letras, Universidade Federal do Amazonas, UFAM, CEP 69077-000, Manaus, AM, Brasil. Doutoranda (bolsista FAPEAM Fundação de Amparo à Pesquisa no Amazonas) do Programa de Pós-Graduação em Literatura Portuguesa, Departamento de Letras Clássicas e Vernáculas, Faculdade de Filosofia, Letras e Ciências Humanas, Universidade de São Paulo, USP, CEP 05508-900, São Paulo, SP, Brasil - niciazucolo@usp.br
} 
Eduardo Sterzi consegue mutilar a ótica da nobreza, ao profanar com sua pena sacrílega o senso comum.

De começo, a capa, como primeira inquietação do leitor.

É uma foto, tirada pelo próprio autor, de uma figura grotesca (escultura?), cujo ângulo privilegia os dentes retorcidos e quebrados da maxila. Não há lábio; a gengiva é deformada; destaca-se o nariz desproporcional (pelo ângulo) na sequência de um espaço escuro, que deveria conter um olho. Do modo como está disposta, a foto pode exigir que o livro seja movimentado, para saber o que está retratado ali: uma espécie de gárgula, deduzo, mas os dentes incisivos também sugerem uma figura vampiresca. A foto, além de reproduzir uma imagem monstruosa, mutila-a: o que compõe a capa é seccionado, de forma a ser apenas parte de algo - talvez - mais grotesco. A matéria do livro?

O livro: aqui estão as palavras, não mais em estado de dicionário, mas em absoluta, fluida e inquietante condição de poesia: violenta e profana poesia.

Antes de o livro começar, uma recepção/apresentação metatextual: "bem-vindo, aleijão: / à minha / imagem / foste feito" (p.7). O aleijão que está sendo bem recebido tanto pode ser o próprio livro, como pode ser o leitor, imagem feita à semelhança do autor. De qualquer forma, a assunção demiúrgica é um fato: “à minha / imagem / foste feito."

Outro poema "fora" do livro é o último. A voz desse poema diz que é "filho de outro buraco", que entrou "desavisado" e saiu "pelo outro lado", num poema intitulado "mais embaixo". Esse texto traz à mente o dito corriqueiro das pequenas resistências: “comigo, o buraco é mais embaixo". Se tomei o primeiro poema como uma apresentação de uma cria, o aleijão, posso entender este último como a autonomia desse aleijão de seu criador: "de onde vim não vim. Sou filho / de outro buraco", ou - por outro viés, já que é plurissignificativo o texto poético - posso considerar como uma grande diversão o processo poético (depois de pronto), e o livro teria sido parido por engano, saindo por outro buraco, que não o de nascimento, por isso, um aleijão. Ou então, posso entender que um parto é doloroso, e a violência que perpassa o livro também se encontra aqui.

Como aqui pretendo uma apresentação do livro, apenas avento possibilidades, como essa, de uma moldura do livro por esses dois poemas. 
Antes de prosseguir, convém destacar que essa moldura foi antecedida por uma invocação, mais que uma epígrafe: um canto sagrado de uma tribo africana, de teor violento e escatológico (em seus dois sentidos), a um ente que vem para matar e salvar.

Aos textos, então...

Já no primeiro poema, o demiurgo avisa: "cuidado ao cão / que morde dentro" (p.11). Isso não subverte o esperado, mudando a preposição e deslocando o foco para a palavra cuidado, rachando-a? Podemos pensar em tomar cuidado, evitando; ou tomar cuidado, tratando, ao cão, que é interno, que morde dentro. Isso não adverte para com o que se vai deparar nas páginas seguintes? Isso não aventa que aleijão é esse com que toparemos?

$\mathrm{Na}$ sequência, um desfile de imperfeições humanas, pequenos aleijões naturalmente aceitos, socialmente adequados e recalcados na forma de "embate dos abraços" (p.24), por exemplo. Deparamo-nos com diversos tempos confrontados na poesia, que não aceita a peia da memória e se insurge, irrompendo na revelação da violência silenciosa que nos vai deformando diariamente.

A desestabilização por que os leitores somos tomados começou na capa, e conduz-nos pelos textos, forçando-nos a um sorriso que se solidifica em esgar quando somos açoitados pela impossibilidade de recomeço, mesmo a $1^{\circ}$ de janeiro (p.103), já que ainda temos "areia nos lábios", e a dança é "na trincheira"... Uma festa que marcaria o início de um novo ano, com novos propósitos ou a dificuldade das relações, cada um de nós (in)defesos, entrincheirados, com areia na gengiva?

"Merda, Sérgio, o ano é de merda, / e o século todo não fede / (mal começa) a outra matéria" (p.116). Potencializando a esperança do início de um novo ano, a esperança de um novo século. Seria assim, se fosse a mansa poesia do nobre.

Mas não é.

Então, o que esperar de uma realidade/natureza violenta, que traz "unhas novas", mas não "novos dentes" (p.109)? Quando "depois do primeiro chute" [...] "só pensa / proteger os olhos / proteger a nuca / proteger a têmpora" (p.98)?

Aleijão é o poeta que profana poesia com a vida, e não tem lugar no cânone beatífico, escrevendo com "porra, / ou água sanitária" (p.35) os seus versos, mutilando a esperança do leitor de encontrar alento nos poemas, revelando-lhe, enfim, que nada mais somos que ocasionais espectadores do movimento da Terra, "no encalço do 
próprio rabo" (p.114), sem transcendência, metafísica ou esperança. Apenas, dura poesia.

Apenas dura poesia encontrada por Eduardo Sterzi, que arrancou as palavras à sua face neutra. Ou não... afinal, esta é apenas uma leitura, não uma chave. Decida, quem ler. 